\title{
The Origin and Jurisdiction of the Municipal Courts in California
}

$\Gamma_{\mathrm{HE}}$ most recent, and, perhaps, among the most important, additions to the California judicial system are the municipal courts, authorized in 1924 by amendments to article VI of the state constitution. ${ }^{1}$ These amendments permitted the establishment of municipal courts in cities or cities and counties operating under charter and having populations of over forty thousand inhabitants and empowered the legislature to provide by general law for their "constitution, regulation, government and procedure." At the next session of the legislature, there was passed what is generally known as the Municipal Court Act. ${ }^{3}$ By its authority, a city or city and county of the privileged class could establish a municipal court by provision in its charter or by a majority vote of its qualified electors. ${ }^{4}$

The first city to take advantage of the Act was Long Beach, which estabhished a municipal court of five judges commencing to function on July 24, 1925. ${ }^{5}$ Los Angeles followed on December 1, 1925, ${ }^{6}$ with a court composed of 24 judges, which number has since been increased to 30.7 The municipal court in San Francisco began to function on July 1,1930 , with 12 judges. $^{8}$ These courts succeeded and displaced in their respective cities the existing justices' and police courts ${ }^{9}$ and also took over the small claims courts. ${ }^{10}$ In Los Angeles county, the inferior courts operating in townships wholly or partly outside the limits of the city in which the municipal court was established continued to function, although excluded from jurisdiction within the city. ${ }^{11}$

The purposes in creating such a court are several, the following being without doubt the most important: first, to provide in the larger cities, where the volume of bitigation is enormous, a co-ordinated system for handling that litigation by means of courts of record functioning

1 CaL. Const. (1924) art. VI, \$§ 1, 5, 11, 12, 14, 18, 24.

2 Ibid. $\$ 11$.

3 Cal. Stats. 1925, p. 648, Cax. GeN. Laws, act 5238.

4 Ibid. \$1.

5 Cal. Stats. 1925, p. 1349; see Wallace v. Payne (1925) 197 Cal. 539, 546, 241 Pac. 479, 882.

6 Bancroft-Whitney Co. v. Payne (1925) 197 Cal. 551, 241 Pac. 551.

7 Cal. Stats. 1931, p. 1537.

8 Ibid. 1929, p. 137.

9 Cas. Const. (1924) art. VI, §11; Car. Gen. Laws, act 5238, \$26; see Bakkenson v. Superior Ct. (1925) 197 Cal. 504, 512, 241 Pac. 874, 876.

10 Hughes v. Municipal Ct. (1926) 200 Cal. 215, 252 Pac. 575; Car. Gen. LAws, act 5238, $\$ 26$.

II Bakkenson v. Superior Ct., supra note 9. 
in conjunction with the superior courts; second, to relieve the congestion in the superior courts to some extent at least; ${ }^{12}$ third, to eliminate the trial de novo of cases appealed from inferior courts. ${ }^{13}$

As happens in every instance of the creation of new courts or the modification of a long continued system of procedure, questions have arisen concerning the jurisdiction of the new court. In view of the tremendous anount of hitigation, both civil and criminal, being handled by the municipal courts, ${ }^{14}$ it is important to stand aside for a time and review some of these questions. We will find that some have been ironed out by annendments to the constitution and the Municipal Court Act and that some have been clarified by judicial decision, but a great many remain unanswered.

I

Use of the term, "municipal," in reference to a court is a fruitful source of ambiguity and confusion as we look closely into questions of jurisdiction. The same is true of the words, "superior" and "inferior." Any of these may be used in their adjectival sense ${ }^{15}$ or as a title or designation of a particular court. The constitution has used and still uses the word, "nuunicipal," in both senses.

12 See opinion of Judge Johnson in Gallagher v. Campodonico (1931) $1 \mathrm{Cal}$. Supp. 205, 209, 5 P. (2d) 486, 489: "But when municipal courts were established and their jurisdiction was extended to cases involving as much as $\$ 2000$, the amendment under review was adopted as part of the plan to relieve congestion in the superior court and to promote expedition and efficiency in the administration of the law?"

13 Section 10 of article VI of the state constitution, as amended in 1924, authorized the legislature to establish appellate departments of the superior courts in counties in which municipal courts should be established. See Cal. Stats. 1923, p. 1678. The legislature did so by blanket provision in 1929. Ibid. 1929, p. 837 . Another 1929 statute provided for the method of appeal froin municipal courts. Ibid. p. 856. It was amended in 1931. Ibid. 1931, p. 1984. In this connection it should be noted that the work of the appellate divisions of the superior courts in San Francisco and Los Angeles counties has demonstrated that the value of tbis method cannot be over-estimated aud is not yet fully appreciated. These courts have expeditiously disposed of a large number of cases appealed from the ununicipal courts, and their written opinions have been recognized as almost on a par with those of the higher courts of the state.

14 From July 1, 1930, to June 30,1931, there were filed in the municipal court in Los Angeles 47,746 civil actions, exclusive of small claims, which numbered 18,587. Criminal complaints numbered 267,723. Report of Fiscal Year 1930-1931, Clerk of Municipal Court, Los Angeles. During the same period there were filed in the inunicipal court in San Francisco 18,035 civil actions and 5,716 small claims. Criminal complaints nunibered 92,797. Report of Clerk of Municipal Court, San Francisco, July 1, 1931.

15 The word, "municipal," is most frequently defined as "pertaining to a city or corporation having the right of local self-government." See In re Werner (1900) 129 Cal. 567, 573, 62 Pac. 97, 99; Bouvier, Law Dictionary (1884) 262. "The term 'Municipal Courts' has a legal meaning and signification, and clearly includes Mayors' and Recorders' Courts . .." Uridias v. Morrill (1863) 22 Cal. 474, 478. See Chinn v. Superior Ct. (1909) 156 Cal. 478, 482, 105 Pac. 580, 581. 
Prior to 1924, the several references to municipal courts in the constitution evidently were meant to describe inferior or city courts. The constitution of 1849 contained the provision that "the Legislature may establish such municipal and other inferior courts as may be deemed necessary." 16 This power was exercised by the creation of a "Municipal Court in the City and County of San Francisco to be called the Superior Court of the City of San Francisco."17 This court, although a court of record ${ }^{18}$ with power to send its original and final processes outside of the city, ${ }^{19}$ was held to be an inferior court. ${ }^{20}$ Its life was very brief, ${ }^{21}$ and in 1862, five years after its abolition, the constitution was amended to omit from section 1 of article VI the reference to municipal courts. We find it, however, inserted in section 10, as follows: "The Legislature shall fix by law the jurisdiction of any Recorder's or other inferior mumcipal Court which may be established in pursuance of section one of this Article..." Under the authority of this section, the legislature created the Municipal Criminal Court of the City and County of San Francisco, ${ }_{2}^{22}$ which was strictly a city court.

The constitution of 1879 did not use the word, "municipal," with reference to courts, but referred to "Justices of the Peace, and such inferior courts as the Legislature may establish in any incorporated city or town, or city and county." 23 It further provided that the powers of the justices of the peace should not in any case trench upon the jurisdiction of the several courts of record, except that provision was made for limited, concurrent jurisdiction with the superior courts in certain cases. $^{24}$

In 1914, however, section $8 \mathrm{I} / 2$ of article XI was amended to allow city charters to provide for "the establishment, constitution, regulation, government and jurisdiction of municipal courts, with such civil and criminal jurisdiction as by law may be conferred upon inferior courts." The amended section also provides that "when such inunicipal court has been established, there shall be no other court inferior to the superior court. . .," and that such courts "shall never be deprived of

16 CAL. Const. (1849) art. VI, §1.

17 Cal. Stats. 1850 , c. 63.

18 People ex rel. Hughes v. Gillespie (1850) 1 Cal. 342. Cal. 157.

19 Hickman v. O'Neal (1858) 10 Cal. 292; Chipman v. Bowman (1859) 14

20 Seale v. Mitchell (1855) 5 Cal. 401. After 1851, when the court was given jurisdiction of all civil cases mvolving over $\$ 200$ and cases involving title to real property in the city, its jurisdiction was practically co-extensive with that of the district courts, the predecessors of the present superior courts.

21 The court was abolished in 1857. Cal. Stats. 1857, p. 128.

22 Cal. Stats. 1870, p. 528 ; Ex parte Stratman (1870) 39 Cal. 517.

23 CAI. Const. (1879) art. VI, $\$ 1$.

24 Ibid. \$11. 
the jurisdiction given inferior courts created by general law." These provisions were manifestly inserted to avoid conflict, as had arisen in the past, ${ }^{25}$ with justices' courts created under general law. The decisions leave no doubt that the municipal courts authorized by this section were inferior courts and not courts of general jurisdiction. ${ }^{26}$

Then, presumably with this background in mind and observing the presence of the provisions contained in section $81 / 2$ of article XI above quoted, the legislature proposed to the people the various amendments to article VI which were adopted in 1924 and which are the source of the present municipal courts. The wording of the amendments is such as to leave no doubt that it was intended to create a new court which was to be not merely a city court but one of general jurisdiction.

Nothing hinges on the precise name of a court, for, as has been said, "to hold this would be to grasp at the form and dsiregard the substance." 27 Justice Preston has described the municipal courts as, "although inferior to the Superior Courts ..., nevertheless superior to inferior courts." 28 Justices' and other inferior courts are not courts of record and their jurisdiction is never presumed. ${ }^{20} \mathrm{It}$ is definitely settled that the mumicipal courts are in a different category..$^{30}$

This conclusion causes us to question the constitutionality and effect of the provisions of the new Charter of the City and County of San Francisco which purport to authorize the mayor to suspend and the board of supervisors to remove any municipal court judge for official misconduct ${ }^{31}$ and otherwise attempt to govern the judges and court attaches. $^{32}$ That the board of freeholders which prepared this charter had in mind the present San Francisco municipal court there is no particular reason to doubt, and in view of the presence of the many able and competent lawyers on that board, we hesitate to question what it has done. There is, perhaps, a question of public policy involved in placing the judges of a court created under legislative act under the control of administrative officers of a city government. Leaving that phase to one side, however, it would follow from the above analysis and

25 Graham v. Mayor \& Board of Trustees of the City of Fresno (1907) 151 Cal. 465, 91 Pac. $14 \%$.

26 Kenyon v. Johnson (1929) 97 Cal. App. 552, 276 Pac. 110; Church v. Board of Supervisors (1931) 211 Cal. 367, 289 Pac. 651; see Robertson v. Langford (1928) 95 Cal. App. 414, 425, 273 Pac. 150, 154.

27 In re Baxter (1906) 3 Cal. App. 716, 720, 86 Pac. 998, 999.

28 In re Luna (1927) 201 Cal. 405, 410, 257 Pac. 76, 87.

20 Jones v. Justice's Ct. (1893) 97 Cal. 523, 32 Pac. 575; Jarrett v. Redman (1926) 79 Cal. App. 482, 250 Pac. 183.

30 Kenyon v. Johnson, supra note 25; Schwartz v. Burnett Pharmacy (1931)

112 Cal. App. 781, 295 Pac. 508; CAL. Const. (1924) art. VI, \$12.

31 S. F. Cerarter (1931) §11, Cal. Stats. 1931, p. 2983.

32 S. F. Charter (1931) $\$ 553-55$, Cal. Stats. 1931, pp. 3009, 3010. 
decisions in analogous cases that the provisions of the San Francisco charter relative to municipal courts are meffective and void. ${ }^{33}$

We must, therefore, consider the municipal courts now established in three cities of the state as distinctive in character. In seeking to determine the extent of their jurisdiction we necessarily come to an analysis of the statute defining it.

$\Pi$

The definition of the municipal courts' jurisdiction in criminal matters has undergone little change and has presented but few difficulties. The courts originally were given jurisdiction over all misdemeanors committed withm their respective counties. ${ }^{34}$ In 1929 , misdenieanors under the control of the juvenile court were made an exception to the general rule. ${ }^{35}$ The court also has all the powers in felony cases granted to committing magistrates. ${ }^{36}$

The real problens arise in connection with civil jurisdiction. The first aspect whicl is important is that the jurisdictions of a superior court and municipal courts in the same county, at least, are mutually exclusive. ${ }^{37}$ A suit brought in the wrong court must necessarily be dismissed for lack of jurisdiction over the subject matter. The Municipal Court Act, as it was amended in 1929, provided that the municipal court should "have exclusive original jurisdiction of all civil cases and actions arising within the city or city and county" of the classes specified. The word, "exclusive," was omitted in the 1931 amendment, ${ }^{38}$ but, nevertheless, due to section 5 of article VI of the constitution, defining the jurisdiction of superior courts, the superior court in the same county generally is without jurisdiction of any case of which a municipal court has jurisdiction..$^{39}$

There is no provision made for a transfer of an action from one court to the other in the event that the parties find themselves for any reason in the wrong court. It is only in the case of suits to foreclose

${ }^{33}$ See Sevier v. Riley (1926) 198 Cal. 170, 244/Pac. 323; Simpson v. Payne (1926) 79 Cal. App. 780, 251 Pac. 324; TutTle, Municrpax Courts (1926) \$4; Opimion of City Att'y, Aug. 17, 1931, in re salaries of attaches of the Municipal Court; ibid. Aug. 31, 1931, in re salaries of Judges of Municipal Courts. .

34 Cal. Stats. 1925 , p. 658.

35 Ibid. 1929, p. 837, CAL. PEN. Code §§ 1461a, 1462; In re Leach (1929) 99 Cal. App. 645, 279 Pac. 157.

36 Cal. Pen. Code $\$ 808$.

37 Hammell v. Superior Ct. (1932) 69 Cal. App. Dec. 1123, 12 P. (2d) 489; Cat. Const. (1928) art. VI, §5; CaL Code Ctv. Proc. \$76.

38 Cal. Stats. 1931 , p. 1717. The italics in the above quotation and those elsewhere in this paper are the writer's.

${ }^{39}$ See authorities cited in note 37, supra. Section 831 of the Code of Civil Procedure provides for concurrent jurisdiction in certain cases, but that such provisions are of doubtful constitutionahity, see Note (1932) 21 CaldF. L. Rev. $42,47$. 
mechanics' liens that a transfer is allowed and then only in order to effect a consolidation of actions pending in both courts. ${ }^{40}$ In view of the numerous questions which come up in practice, some of which are discussed in this article, it is submitted that it would tend to expedite the conduct of hitigation and serve the ends of justice if proper statutory enactment could be made which would have the following effect: Where it appears that through mistake or inadvertence a suit is brought in a trial court which has no jurisdiction of the subject matter of that suit and it further is made to appear that another trial court has such jurisdiction, then the court in which the suit is brought shall have the power to transfer such action together with all records concerning it to the proper court. Such a provision, although rather more limited in scope, is found applicable to justices' courts.11 There is no reason why the line of cleavage should be so strictly drawn as to the municipal courts.

An apt illustration of the possible application of such a procedure can be found in connection with the question of the amount of money - demand. The Act gives the municipal court jurisdiction where "the demand, exclusive of interest, or where the value of the property in controversy, amounts to two thousand dollars or less." 42 It has been held that where several plaintiffs each with a demand under the jurisdictional amount join together in a single action, in effect thereby consolidating several actions, the municipal court has jurisdiction although the aggregate of the demands exceed that amount.43 Recently it was held that where several claimants eacl with a small demand assign to a single plaintiff, although the total of all demands amounts to over $\$ 2000$, the superior court is without jurisdiction to hear the action. ${ }^{44}$ In the latter instance, if the superior court had had the power to do so, it manifestly would have been better to transfer the case to the municipal court rather than compel the plaintiff to commence a new action.

\section{III}

The next question to be determined is where the cause of action arises. ${ }^{15}$ This question was particularly troublesome in Los Angeles county under the Act as originally passed. There, if the cause of action arose outside of the city limits, the action could still be brought in either

40 Cax. GeN. LaWs, act 5238, $\$ 29$ (1) (d).

41 CaI. Code Crv. Proc. \$838. But that such provisions may be unconstitutional where jurisdiction is defined by the constitution, see Note (1932) 21 CAIIF. L. REv. $42,51$.

12 Cax. Gen. Laws, act 5238, $\$ 29$ (1) (a).

13 Colla v. Carmichael U-Drive Autos (1930) 111 Cal. App. 784, 294 Pac. 378.

14 Hammell v. Superior Ct., stipra note 37.

45 The Act makes jurisdiction turn upon where the "case" arises, but "case" bas been construed, in this instance, to mean cause of action. Johnston v. Wolf (1929) 208 Cal. 286, 280 Pac. 980. 
the justices' courts or the superior court, depending upon the amount involved. ${ }^{48}$ If the cause of action arose within the city, the jurisdiction of the municipal court was exclusive.47 Thus jurisdiction was made to depend on where, within the confines of a single county, the cause of action arose. Much confusion necessarily resulted from this situation. ${ }^{48}$

Bound up with this difficulty was the further question as to the right to appeal to a district court of appeal from a judgment of a superior court acting in its capacity as an appellate court affirming or reversing a judgment of a municipal court. Prior to 1928, the district courts of appeal had jurisdiction to hear the appeal regardless of where the case was originally commenced and tried. ${ }^{49}$ In that year a new section was added to the constitution which limited the right of appeal to those cases in which the superior court had original jurisdiction. ${ }^{50}$ Section 5 of article VI was amended to give the superior court original jurisdiction of all civil cases and proceedings except those of which municipal or justices' courts had or should be given jurisdiction. These amendments were followed in 1929 by an amendment of the Municipal Court Act which omitted from the definition of the municipal court's jurisdiction of cases arising outside the city and within the county the provision that it should be concurrent with that of the superior and justices' courts, thus excluding the superior court from original jurisdiction and so solving the immediate problem. There is no longer, therefore, any appeal from a judgment of a municipal court beyond the superior court, ${ }^{51}$ unless it be by way of a writ im matters involving acts done in excess of jurisdiction.

Taking the statute as it now is, we still have certain requirements which raise the question as to where a cause of action arises. In the writer's opinion, there is still much that can be done in the way of

16 Johnston v. Wolf, supra note 45 ; Berg v. Traeger (1930) 210 Cal. 323, 292 Pac. 495 (concurrent with superior court) ; Borden v. Thomas (1927) 85 Cal. App. 646, 259 Pac. 1008 (concurrent with justices' court). That the provision for concurrent jurisdiction possibly was unconstitutional, see Note (1932) 21 CALIF. L. REv. 42,47 .

47 Nelson v. Thomas (1930) 103 Cal. App. 108, 283 Pac. 982; Nelson v. Darling (1930) 103 Cal. App. 523, 284 Pac. 1095; cf. Williams Co. v. Superior Ct. (1929) 97 Cal. App. 422, 275 Pac. 838.

48 See Willis, Civil Jurisdiction of Municipal Courts (1931) 6 L. A. BAR Ass'N BULx, 203.

49 Harris v. Moore (1929) 102 Cal. App. 413, 283 Pac. 76; Jones v. Summers (1930) 105 Cal. App. 51, 286 Pac. 1093; Fleming v. Dolfin (1930) 108 Cal. App. 740, 292 Pac. 498.

50 CaL. Const. (1928) art. VI, $\S 4 \mathrm{~b}$. The cases cited in note 49 , supra, held that this amendment was not retroactive.

51 Moye v. National Surety Co. (1929) 208 Cal. 279, 280 Pac. 982; Berg v. Traeger, supra note 46; Herbold v. Atchison, T. \& S. F. Ry. (1931) 117 Cal. App. 430, 4 P. (2d) 184. Certain cases covered by section 831 of the Code of Civil Procedure are possible exceptions. See note 39 , supra. 
simplification and clarification, and this is said with no lack of respect to the franiers of the Act. The nunicipal court is as yet in the experimental stage, and the test of legislation is in the laboratory of the courtrooni.

The court's jurisdiction is extended to cases arising outside of the county, excepting actions of forcible or unlawful detainer and to foreclose mechanics' liens. ${ }^{52}$ Then follow several specific provisos: First, all proper defendants who are residents of California must reside in the county where the court is established and (not "or") any property involved must be located there. Second, a further exception excludes cases arising in another city where a municipal court is established. Third, where the action involves less than $\$ 300$, jurisdiction is acquired where $a$ (not "all") proper defendant resides or has a regular place of business in the county and (again not "or") any property involved is located in the county.

Far from avoiding a discussion as to where a cause of action arises, these provisions throw us back into it. If the contention seriously can be made that the cause of action arose outside of the county where the court fimctions, a doubt is at once cast upon its power to proceed with the case. The question is one of jurisdiction over the subject matter and hence cannot be waived by the voluntary appearance or consent of the defendant. ${ }^{53}$ It is not an answer to say that in any event the defendant has lis right to change the place of trial upon a proper motion for that purpose, as the court, being without jurisdiction, can not even pass upon that motion. ${ }^{54}$ Under the statute, then, we must first determine where the cause of action arose, and, if it arose outside the county, we must then proceed to find out who are the proper defendants, where they reside, and where the property, if any is involved, is located. It is hardly necessary to add that the determination of the question of where the cause of action arose in a given case frequently is a difficult one and calls forth wide difference of opinion..$^{5 \overline{5}}$

The second proviso, that juridiction is lacking if the cause of action arose in a city where there is already a municipal court, taken by itself, seems unambiguous. The inconvenience may, lowever, be one of geography and expense of travel. Suppose a plaintiff, residing in San Francisco, desires to sue another resident of that city in a case over which the San Francisco municipal court would have jurisdiction except for

52 CAI. GEN. LAWS, act 5238, $\$ 29$ (3).

53 Herrington v. Superior Ct. (1924) 194 Cal. 185, 228 Pac. 15.

54 Maguire v. Cunningham (1923) 64 Cal. App. 536, 542, 222 Pac. 838, 841.

55 Southwestern Portland Cement Co. v. Cochrane (1931) 114 Cal. App. 778, 300 Pac. 445 (suit upon stockholders liability involving question whether cause of action arose in City of Glendale or City of Los Angeles); cf. Molfino v. Pippo (1932) 69 Cal App. Dec. 243, 10 P. (2d) 78. 
the fact that it appears that the cause of action arose in the city of Los Angeles. Both parties may be called upon to adjourn to Los Angeles to find a court which can hear their case. ${ }^{56}$

The third qualification makes a different rule for suits involving less than $\$ 300$ which seems a trifle more liberal than that pertaining to those which involve more. Exactly why this or any other arbitrary money line is drawn is not quite clear. Litigants suing for a little less or a little more would be justified in wondering why there should be any distinction. To simphify this it is submitted that section 29 (3) of the Municipal Court Act be amended to read substantially as follows:

Each Municipal Court shall have original jurisdiction of all cases specified in subdivisions (a) and (c) of said subdivision 1 arising outside the county or city and county in which such Municipal Court is established, in which either one or inore persons properly joined as defendants is or are residents of the county in which said Municipal Court is estbalished, or, if property is involved, when said property is located in said county.

\section{IV}

The next provision to which we desire to direct attention is that portion of section 29 which gives the court jurisdiction in "all cases at law in which," etc. This is followed in subdivision 4 by a provision extending the jurisdiction to "all cases in equity when pleaded as defensive matter or by way of cross-complaint in any case properly pending in such municipal court." In other words, a plaintiff suing in the municipal court cannot ask for equitable relief, but the defendant can. It would be interesting to consider how far the court could go in granting such relief to the defendant in fairness without being unjust to the plaintiff who brought the suit and who is deprived of an equality of position in this regard.

In any event, this distinction is the sourse of constant argument and objections to the jurisdiction by attorneys and properly so. It brings up again the division of the courts into the law side and the equity side. The tendency for years has been to abolish this, and we are all familiar with the provision in the Code of Civil Procedure that there is but one form of civil action in this state. ${ }^{57}$

Certain classes of cases are easily classified by the practicing lawyer and the judge as belonging to one group or the other, but there is a large number of cases which it is extremely difficult to determine whether to bring as actions "at law" or suits "in equity." Cases involving fraud or rescission of contracts are examples. Apparently, if the plaintiff can maintain that a rescission has taken place, he may sue in the

E6 For discussion of this possibility, see Note (1932) 21 CarIF. L. REv. $42,43$. 5t Cal. Code Crv. Proc. \$307. 
municipal court for damages for fraud in the making of the contract.58 Suppose that in the same case the defendant denies that there has been such a rescission,- -has the court the power to determine that issue? If it can determine that a rescission has been effected, what objection can there be to allowing the court to make a decree of rescission where there has been no rescission prior to suit? The same thing arises where, for all practical purposes, an accounting is forced as a necessary incident to the suit.

Another example involves the question of a creditor's bill after supplementary proceedings. If this is to be regarded as solely an equitable proceeding, as it has been held to be, ${ }^{59}$ it becomes necessary for the creditor to bring a new action in the superior court even though the amount imvolved is small. To this extent, the municipal court is not allowed to enforce its own judgment.

This suggests a further complication in connection with the use of auxiliary remedies, as distinguished from causes of action. For example, a suit for a pernianent injunction is known to be equitable in character, but a temporary injunction or restraining order may be used in a variety of actions as an auxihary renedy ${ }^{60}$ or for the same purpose as an attachment. In matters of procedure, the Code of Civil Procedure first provides that "the rules of pleading and practice applicable to the prosecution of civil actions and enforcement of judgments in the superior court of this State shall apply to and govern in the Municipal Courts," with certain changes. ${ }^{61}$ In a negative fashion the code then omits from the description of the procedure of the municipal court those sections pertaining to injunctions and the appointment of receivers. ${ }^{62}$ This results in completely forbidding to the plaintiff any application for an injunction or appointment of a receiver in the municipal court at any stage of the proceedings. It has been held by the appellate division of the San Francisco superior court that the municipal court, in view of the above.provision in the Code of Civil Procedure, has no jurisdiction to appoint a receiver. ${ }^{63}$ Whether this principle should extend to all cases is a question, and the argument that an exception should be made where the application is made solely for the purpose of enforcing a judgment carries much force. As to an application for equitable relief (which would include an injunction), made by a de-

68 Taback v. Greenberg (1930) 108 Cal. App. 759, 292 Pac. 279; cf. Freligh v. McGrew (1928) 95 Cal. App. 251, 272 Pac. 791; see Note, post page 130.

69 Phillips v. Price (1903) 153 Cal. 146, 94 Pac. 617.

60 Injunctions in the Code of Civil Procedure are included under Title VII, "Provisional remedies in civil actions".

61 Cat. Code Civ. Proc. §§ 831c, 831d.

62 Ibid. §831e.

63 Bosshardt v. Siminons (1932) unreported. 
fendant, we note the apparent conflict which arises from the wording of the Municipal Court Act that the municipal court has jurisdiction in all cases in equity when pleaded as defensive matter.

This lack of clarity in the statutes and the various restrictions they contain unnecessarily hamper the flexibility and efficiency of the municipal court. Increased power, particularly in connection with the enforcement of judgments, could be given without unduly encroaching upon the functions of the superior court. In matters of procedure, simplicity of rules is greatly to be desired. Simplicity can, and should be, accomplished by a few amendnients to the law as it is now written. The writer respectfully makes the suggestion, therefore, that section 831e of the Code of Civil Procedure be repealed and that the Municipal Court Act be amended so that paragraph (a) of subdivision 1 of section 29 will read substantially as follows:

All cases in which the demand, exclusive of interest or the value of the property in controversy, amounts to two thousand dollars or less; provided, that said jurisdiction shall in no instance extend to include actions or proceedings in insolvency, to prevent or abate a nuisance, for divorce or annulment of marriage, to quiet title to or for the partition of real property, matters of probate, naturalization or other special proceedings over which the Superior Court has or may be given exclusive jurisdiction.

Subdivision 4 of the same section should also be repealed in order to ehminate any difference in the rights of plaintiffs and defendants. It is submitted that these changes would do away with many technical arguments.

\section{$\mathrm{V}$}

The remaining portions of section 29 of the Act have not, as yet, appeared difficult of application. The court is given jurisdiction in actions of forcible entry or forcible or unlawful detainer where the rental value is two hundred dollars per nonth, or less. There is also permitted actions to foreclose liens on personal property and mechanic's liens on real property where the aniount is two thousand dollars, or less. It is to be noted that these provisions as to foreclosure of liens are for equitable rehef and have been given a liberal interpretation.

Gallagher v. Campodonico ${ }^{64}$ was an action brought to foreclose a lien for street work done under contract between the owner of the property and the plaintiff, as contractor. The objection was made and sustained by the trial court that the court lad no jurisdiction to foreclose a lien of a contractor, as that was not specifically included. After a very careful analysis, Judge Johnson comes to the conclusion that a proper construction of the statute would include a contractor's lien, as it may be fairly said that the purpose of the legislative enactment was not, by

64 Supra note 12 . 
the mere omission of the words, to exclude a class of liens which would certainly normally be grouped with liens of mechanics, materialmen and laborers. He says that while this construction "will not be pressed beyond the fair import of the legislative grant yet, doubts may be resolved in favor of jurisdiction (under a new statute), unless some established rule of law is violated." This expression is indicative of the attitude of the appellate courts im construing questions concerning the scope and jurisdiction of the mumicipal courts.

Believing as we do that the mumicipal courts already have proved themselves to be an important addition to our judicial system, those of us who actively participate in the work are appreciative of the assistance which has been rendered by the legislature and the higher courts. The suggestions made here are aimed solely at the abolishing of technicalities which seem unnecessary and tend to destroy efficiency. If the writer's suggestions serve to present in a little clearer light the problems which have to be met in the daily operation of these courts, the purpose of this article has been accomplished.

Alden Ames.

San Francisco, California. 